Article

\title{
Presence of Known and Emerging Honey Bee Pathogens in Apiaries of Veneto Region (Northeast of Italy) during Spring 2020 and 2021
}

\author{
Fulvio Bordin * ${ }^{\dagger}\left(\mathbb{D}\right.$, Laura Zulian ${ }^{\dagger}$, Anna Granato (D), Mauro Caldon, Rosa Colamonico, Marica Toson, \\ Laura Trevisan, Laura Biasion and Franco Mutinelli (D)
}

check for

updates

Citation: Bordin, F.; Zulian, L.;

Granato, A.; Caldon, M.; Colamonico,

R.; Toson, M.; Trevisan, L.; Biasion, L.;

Mutinelli, F. Presence of Known and

Emerging Honey Bee Pathogens in

Apiaries of Veneto Region (Northeast

of Italy) during Spring 2020 and 2021.

Appl. Sci. 2022, 12, 2134. https://

doi.org/10.3390/app12042134

Academic Editor: Jerzy Wilde

Received: 28 January 2022

Accepted: 16 February 2022

Published: 18 February 2022

Publisher's Note: MDPI stays neutral with regard to jurisdictional claims in published maps and institutional affiliations.

Copyright: () 2022 by the authors. Licensee MDPI, Basel, Switzerland. This article is an open access article distributed under the terms and conditions of the Creative Commons Attribution (CC BY) license (https:/ / creativecommons.org/licenses/by/ $4.0 /)$.
National Reference Laboratory for Honey Bee Health, Istituto Zooprofilattico Sperimentale delle Venezie, Viale dell’Università 10, 35020 Legnaro, Italy; lzulian@izsvenezie.it (L.Z.); agranato@izsvenezie.it (A.G.); mcaldon@izsvenezie.it (M.C.); rcolamonico@izsvenezie.it (R.C.); mtoson@izsvenezie.it (M.T.); ltrevisan@izsvenezie.it (L.T.); lbiasion@izsvenezie.it (L.B.); fmutinelli@izsvenezie.it (F.M.)

* Correspondence: fbordin@izsvenezie.it

+ These authors contributed equally to this work.

\begin{abstract}
A progressive honey bee population decline has been reported worldwide during the last decades, and it could be attributed to several causes, in particular to the presence of pathogens and parasites that can act individually or in synergy. The health status of nine apiaries located in different areas of the Veneto region (northeast of Italy) was assessed for two consecutive years (2020 and 2021) in spring, during the resumption of honey bee activity, for determining the presence of known (Nosema spp., Varroa mite and viruses) and less known or emerging pathogens (Lotmaria passim and Crithidia mellificae) in honey bees. After honey bees sampling from each of the nine apiaries, Nosema apis, Nosema ceranae, L. passim, C. mellificae, ABPV, CBPV, IAPV, KBV, BQCV, SBV, DWV-A, $\mathrm{DWV}-\mathrm{B}$ and $V$. destructor were investigated either by microscopic observation or PCR protocols. The viruses BQCV, SBV, CBPV followed by N. ceranae and L. passim were the most prevalent pathogens, and many of the investigated hives, despite asymptomatic, had different degrees of co-infection. This study aimed to highlight, during the resumption of honey bee activity in spring, the prevalence and spreading in the regional territory of different honey bee pathogens, which could alone or synergistically alter the homeostasis of bees colonies. The information gathered would increase our knowledge about the presence of these microorganisms and parasites in the territory and could contribute to improve beekeepers practice.
\end{abstract}

Keywords: honey bee; Italy; microscopy; Nosema spp.; pathogen; PCR; real time RT-PCR; RT-PCR; trypanosomatids; virus; Varroa

\section{Introduction}

Honey bees (Apis mellifera) health status has been an important scientific topic in the last years, and the global decline in populations of both managed and wild honey bees has been reported as one of the most severe ecological and economic problems worldwide [1]. To date, honey bee colony losses recognize no single cause, but the interactions between multiple biotic (e.g., pathogens, bee genetics, and queen longevity) and abiotic (e.g., agrochemical exposure, forage quality, management practices and climate change) factors are contributing to reduce populations of these pollinators [2,3]. While studies on the quality of environmental conditions are giving well-established information about their impact on bee health, the role of pathogens such as the microsporidia Nosema spp., trypanosomatids, viruses and the ectoparasitic mite Varroa destructor in colony mortality and the relationships between their prevalence and abundance have not been fully elucidated and require further investigation. The beekeeping sector is receiving support from the European Union [4], also co-financed by the member states, with the aim to promote the production and marketing 
of its products, given also the growing impact of certain pathogens on the health status of honey bees, for the qualitative and quantitative improvement of agricultural production and natural ecosystems.

The resumption of activity in spring is an important moment for the development of the bee colony and it is influenced by both the interventions carried out by beekeepers in the previous autumn and winter seasons and the pathogens occurrence in the hives. To date most pathogens and parasites affecting honey bees have an almost worldwide distribution [5,6], and they include viruses, fungi, bacteria, protozoa and parasitic mites which, alone or in association [7,8], or as a result of particular environmental or hive conditions, could affect the health of the apiaries.

It is well known that both Nosema spp. (Nosema apis and Nosema ceranae) and several viruses are a major cause of honey bee diseases. Nosema spp. can affect the productivity and survival of honey bees altering their longevity and behaviour, brood rearing and pollen collection $[9,10]$. It was also reported that co-infection by virus and $N$. ceranae in honey bees might be associated with colony collapse disorder (CCD) [11]. Currently, more than 30 viruses have been identified in honey bee populations [6] and multiple viral infections have been reported in bees [12-17]. Six of these viruses can be responsible for severe diseases in honey bees: acute bee paralysis virus (ABPV), black queen cell virus (BQCV), chronic bee paralysis virus (CBPV), deformed wing virus (DWV), Israeli acute paralysis virus (IAPV), Kashmir bee virus (KBV), and sac-brood virus (SBV). These pathogens can attack different developmental stages of the honey bees including eggs, larvae, pupae, adult worker, drones and queens. Their transmission can occur both horizontally between bees and vertically from queen to offspring.

ABPV, KBV and IAPV are closely related dicistroviruses $[18,19]$ that normally persist at a low level of infection within the colony, with no obvious symptoms at the individual or colony level. However, they are extremely virulent when injected into pupae or adults [20]. Considering these features upon injection into the bee haemolymph, it is not surprising that they are usually related to $V$. destructor, which, when feeding on the bee's haemolymph, can transfer ABPV among the colony, causing paralysis of adult bees and death in a short time. While ABPV and IAPV have been reported to result in rapidly progressing paralysis and death of honey bees [21,22], KBV affects both brood and adult bees with no visually detectable clinical symptoms and can be spread between bees and from the queen to her offspring [23].

BQCV is one of the most prevalent and widespread viruses in honey bee colonies, with a constant annual incidence in the adult population. Although BQCV does not cause visible symptoms in infected adult bees, it can kill queen larvae and pupae by turning their cells black [24]. BQCV has been related with Nosema spp. infestation and other viruses [25], but it is still unclear how they are linked.

CBPV is an unclassified bipartite RNA virus [26] with a worldwide distribution, above all in Asia, Europe and North America [27-29], causing a rare but severe chronic paralysis. Infected honey bees show abnormal trembling, making them unable to fly, and darker, hairless abdomens [30]. Symptomatic individuals seems to be too weakened for pollination or honey production and often die in few days [21,31], leading to mounds of dead bees outside affected colonies, which sometimes collapse.

SBV and DWV are single-stranded positive-sense RNA virus members of the Iflavirus genus $[30,32,33]$. SBV was the first virus identified in honey bees and is transmitted to larvae by SBV-infected nurse bees [34], leading the larvae to fail to pupate [35,36], acquire a sac-like appearance and finally die. SBV can also affect adult bees without clinical signs of disease, even if such bees may have a shorter life span $[37,38]$. The virus may remain viable in dead larvae, honey, or pollen for weeks, so the infection can be further spread from one hive to another through swarming and drifting of the virus-infected colonies.

DWV is transmitted vertically and horizontally by the ectoparasite $V$. destructor $[32,39]$, causing deformed wings and shortened abdomens often observed on honey bees with a reduced life span $[23,39,40]$, associated with bee colony weakening and mortality. Three 
genetic variants of DWV were discovered and identified as types $\mathrm{A}, \mathrm{B}$, and $\mathrm{C}$, but the DWV-A and -B are the most widespread variants [41,42].

As with viruses, $V$. destructor mite is also largely widespread and it weakens the bees, feeding on the fat body [43] both of adult bees and their brood. Many studies shown that it also acts as a vector for many viruses affecting honey bees [44], in particular DWV, leading to the speculation that viruses and mites had a synergistic negative effect on the honey bee colonies $[45,46]$. However, the mechanisms that underlie Varroa-mediated vectoring and transmission of viruses to honey bees remain poorly understood and the correlation between virus detection and Varroa-infestation level is still not so clear [47].

The trypanosomatids Crithidia mellificae and Lotmaria passim are unicellular obligate parasites that infect $A$. mellifera colonizing the digestive system [48,49]. C. mellificae was described for the first time in 1967 [50], while Schwarz et al. [48] recently characterized L. passim. These pathogens are currently receiving much attention given that their presence has been correlated with colony losses especially when detected in association with $N$. ceranae [51-54], even if their potential pathogenicity and prevalence have not been fully elucidated $[55,56]$. However, nowadays L. passim appears to be the predominant one in honey bees worldwide, in contrast to C. mellificae [57-60].

The purpose of this study was to monitor the health status of nine apiaries situated in the Veneto region (northeast of Italy) during spring of 2020 and 2021, evaluating the presence and prevalence in honey bee colonies of 13 pathogens, known and less known or emergent (i.e., L. passim, C. mellificae, DWV variants). To date, there is a lack of information on the occurrence and spread in the Veneto region, and generally in Italy, so different honey bee colonies across different geographic areas were studied. In this way, we could stimulate and extend epidemiological studies aimed at investigating the potential relationships between colony health and pathogen occurrence and their dynamics on a larger scale, and possibly compare these results with data originating from colonies in the surrounding European countries [61].

\section{Materials and Methods}

\subsection{Sample Collection}

According to the Italian National Beekeeping Registry (as of 31 December 2021), the Veneto region recorded 8470 beekeepers, 15,830 apiaries and 128,592 colonies with a mean density of 0.8628 apiary $/ \mathrm{km}^{2}$.

A total of 180 clinically healthy honey bee (A. mellifera) colonies from 9 apiaries (10 hives per apiary) distributed over different geographical areas (plain, hills, mountains) of the Veneto region (northeast of Italy) and belonging to different beekeepers were identified. Each apiary has been marked with a letter from A to I (Figure 1), and a specific form has been prepared for the collection data on beekeepers, on geographical information about the territory in which the apiary was located, on the nearby crops and human activities, on disease and Varroa mite infestation, on possible treatments against Varroa carried out in the previous autumn/winter season and on previous poisoning due to phytochemical treatments.

The apiary A was located in the mountains, within a natural context consisting of meadows for fodder production $\left(0.6297\right.$ apiary $\left./ \mathrm{km}^{2}\right)$. The apiaries $\mathrm{E}\left(1.3595\right.$ apiary $\left./ \mathrm{km}^{2}\right)$, $\mathrm{G}\left(1.3813\right.$ apiary $\left./ \mathrm{km}^{2}\right), \mathrm{H}\left(1.3595\right.$ apiary $\left./ \mathrm{km}^{2}\right)$, and I $\left(0.7765\right.$ apiary $\left./ \mathrm{km}^{2}\right)$ were located in the hills, mostly in an agricultural environment in which fruit trees (Pomacee, Drupacee, grapevine and olive tree), cereal, forage, horticultural and ornamental flower crops were present, with the exception of the apiary $\mathrm{F}$ located in an agricultural/urban/industrial context. The apiaries B (1.3595 apiary $\left./ \mathrm{km}^{2}\right), \mathrm{C}, \mathrm{D}$, and F (1.1209 apiary $\left./ \mathrm{km}^{2}\right)$ were located in the plain, in an agricultural and/or urban context characterized by the presence of poplars and ornamental flower crops or greenhouses and horticultural, cereal and forage crops or cereal and forage crops (Figure 1). 


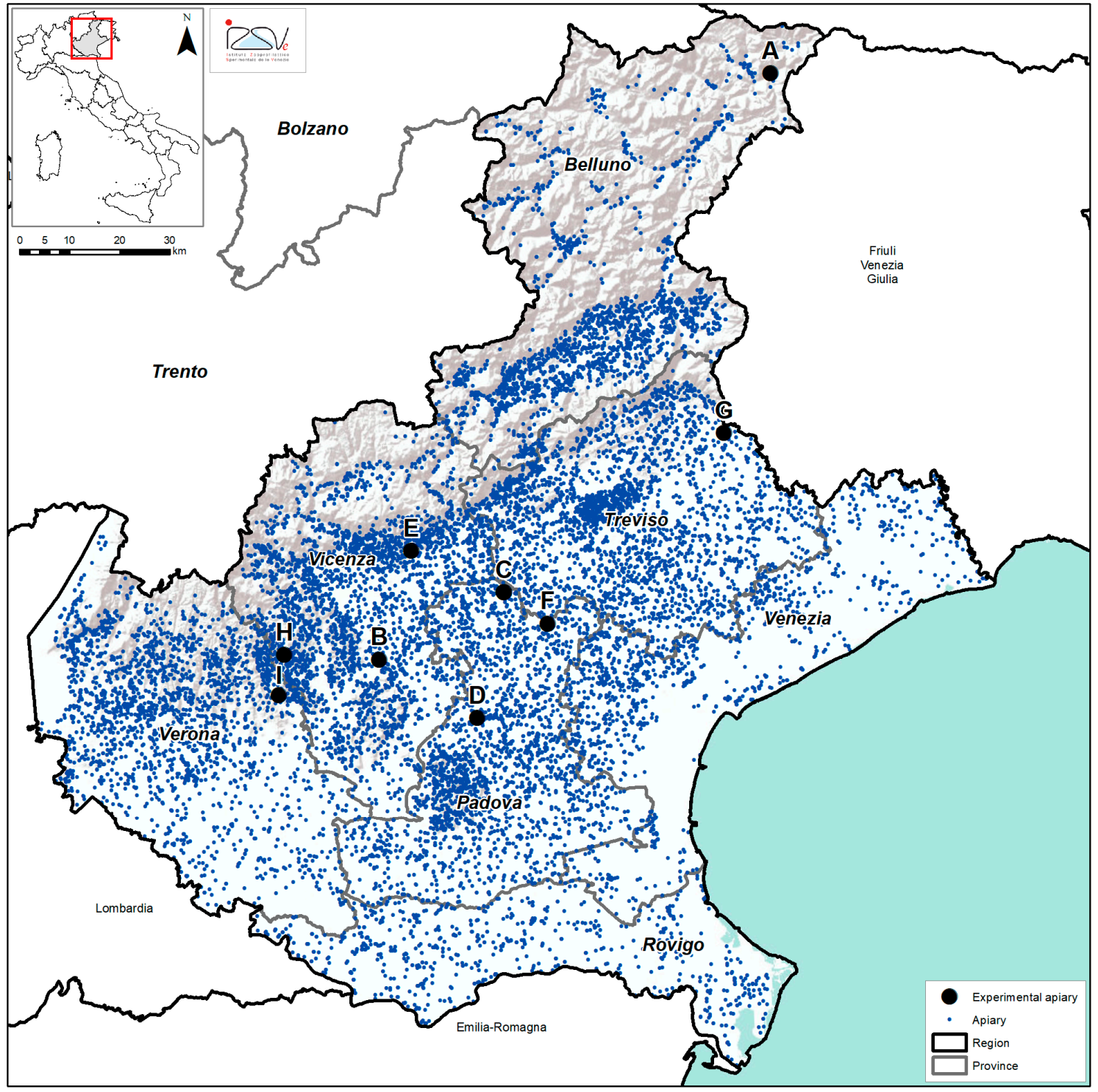

Figure 1. Veneto region (north-east of Italy): distribution of the apiaries involved in the study. Each apiary has been marked with a letter from A to I. Source: Base map from ESRI, USGS, NOAA (ArcGIS Desktop Licence 10.5.1).

Between the end of April and the beginning of May both in 2020 and 2021, about 90 honey bees from each of the 10 hives of each apiary were sampled from the flight board and then stored at $-20^{\circ} \mathrm{C}$ until analysis. Unfortunately, honey bees were collected only from 171 out of 180 selected hives since in 2020 we received samples from only 1 of the 10 hives of apiary A. Varroa infestation was assessed in the field with the powdered sugar test as indicated in the OIE Manual [62]) and detected mites were collected.

Meteorological data were available from the website (www.arpa.veneto.it (accessed on 14 February 2022) of the Environment Protection Agency of Veneto region.

\subsection{Nosema spp.}

For Nosema spp. spores detection and quantification, a homogenate of 60 bee abdomens was analysed by light microscopy at $400 \times$ according to the OIE Manual of Diagnostic Tests and Vaccines for Terrestrial Animals chapter 3.2.4, paragraph B.1.1 [62]. The Nosema spp. positive samples were analysed for Nosema species (Nosema apis / Nosema ceranae) identification. DNA extraction was performed from $1 \mathrm{~mL}$ homogenate using the QIAamp ${ }^{\circledR}$ DNA Mini Kit (Qiagen, Hilden, Germany) according to the manufacturer's instructions, with a 
lysozyme pre-incubation step. The yield and purity (260/280 and 260/230 nm absorbance ratios) of DNA was determined using the Nanodrop ${ }^{\mathrm{TM}}$ One C (Thermo Fisher Scientific, Waltham, MA, USA) spectrophotometer. The DNA was stored at $-20{ }^{\circ} \mathrm{C}$ until use. For $N$. apis and $N$. ceranae identification, two different sets of primers described by MartínHernández et al. [63] were used. PCR was performed in a final volume of $50 \mu \mathrm{L}$ using AmpliTaq $^{\mathrm{TM}}$ Gold kit (Applied Biosystems ${ }^{\mathrm{TM}}$, Waltham, MA, USA), with 200 ng of DNA and containing a final concentration of $0.25 \mu \mathrm{M}$ for each primers and $0.2 \mathrm{mM}$ of dNTPs. The PCR was carried out using a Veriti ${ }^{\mathrm{TM}}$ 96-Well Thermal Cycler (Applied Biosystems ${ }^{\mathrm{TM}}$, Waltham, MA, USA), and the thermal cycling profile consisted of an initial denaturation step at $95^{\circ} \mathrm{C}$ for $10 \mathrm{~min}$ followed by 35 cycles consisting of denaturation at $94{ }^{\circ} \mathrm{C}$ for $15 \mathrm{~s}$, annealing at $62{ }^{\circ} \mathrm{C}$ for $30 \mathrm{~s}$, extension at $72{ }^{\circ} \mathrm{C}$ for $30 \mathrm{~s}$ and a final elongation step at $72{ }^{\circ} \mathrm{C}$ for 7 min. Negative and positive controls were included in each PCR. Amplification products (218 bp for N. ceranae and 312 bp for N. apis) were analysed by capillary electrophoresis on LabChip GX Touch HT $^{\circledR}$ (Perkin Elmer, Waltham, MA USA).

\subsection{Lotmaria passim and Crithidia mellificae}

To detect the presence of C. mellificae and L. passim, the starting material was the same homogenate of 60 bees' abdomens prepared for Nosema spp. spores analysis. DNA extraction and PCR were performed as described in paragraph 2.2. For C. mellificae and L. passim detection, two different sets of primers described by Bartolomé et al. [64] (Table 1) were used. For $C$. mellificae, a final concentration of $0.25 \mu \mathrm{M}$ of primers, $0.2 \mathrm{mM}$ of dNTPs and $1.5 \mathrm{mM}$ of $\mathrm{MgCl}_{2}$ were used, while for $L$. passim, the final concentration was $0.3 \mu \mathrm{M}$ for primers, $0.2 \mathrm{mM}$ for $\mathrm{dNTPs}$ and $2 \mathrm{mM}$ for $\mathrm{MgCl}_{2}$. PCR reactions were performed on a Veriti ${ }^{\mathrm{TM}}$ 96-Well Thermal Cycler (Applied Biosystems ${ }^{\mathrm{TM}}$, Waltham, MA, USA) and the thermal cycling profile consisted of an initial denaturation step at $95{ }^{\circ} \mathrm{C}$ for $10 \mathrm{~min}$, followed by 45 cycles consisting of denaturation at $94{ }^{\circ} \mathrm{C}$ for $30 \mathrm{~s}$, annealing for $30 \mathrm{~s}$ at $58{ }^{\circ} \mathrm{C}$ for C. mellificae or $68^{\circ} \mathrm{C}$ for L. passim and extension at $72{ }^{\circ} \mathrm{C}$ for $10 \mathrm{~s}$, with a final elongation of $7 \mathrm{~min}$ at $72{ }^{\circ} \mathrm{C}$. PCR products of $254 \mathrm{bp}$ and $177 \mathrm{bp}$ of the genes encoding, respectively, for the RNA polymerase II large subunit (RBP1) of L. passim and the glyceraldehyde-3-phosphate dehydrogenase (GAPDH) of C. mellificae were analysed by capillary electrophoresis on LabChip GX Touch HT ${ }^{\circledR}$ (Perkin Elmer, Waltham, MA, USA).

Table 1. Type of analysis, investigated pathogens and references of primers and probes.

\begin{tabular}{ccc}
\hline Analysis & Pathogens & References \\
\hline PCR & Crithidia mellificae & {$[64]$} \\
& Lotmaria passim & {$[64]$} \\
& Nosema apis/Nosema ceranae & {$[63]$} \\
RT-PCR & IAPV & {$[65]$} \\
& KBV & {$[66]$} \\
& ABPV & {$[67]$} \\
Real Time RT-PCR & BQCV & {$[68]$} \\
& DWV-A/DWV-B & {$[69]$} \\
& CBPV & {$[70]$} \\
\hline
\end{tabular}

\subsection{Honey Bee Viruses}

Honey bee samples were analysed for eight honey bee viruses relevant in respect to colony health status: ABPV, CBPV, DWV-A and DWV-B, SBV, BQCV, KBV and IAPV.

From each hive a pool of five honey bees were analysed after homogenization by Tissue Lyser II (Qiagen, Hilden, Germany) (2 cycles, 1 min each, at $30 \mathrm{~Hz}$ ) in the presence of a $5 \mathrm{~mm}$ stainless steel bead. Total RNA extraction was performed on KingFisher Flex Purification System (Thermo Fisher Scientific, Waltham, MA, USA) for automated nucleic acid purification using the MagMAX ${ }^{\mathrm{TM}}$ Pathogen RNA/DNA Kit (Applied Biosystems ${ }^{\mathrm{TM}}$, 
Waltham, MA, USA), according to the manufacturer's instructions. To detect viral RNA both real time RT-PCR and end point RT-PCR were performed.

For ABPV, CBPV, DWV-A, DWV-B, SBV and BQCV the amplification reactions were carried out on CFX96 Real-Time detection System (Bio-Rad Laboratories Inc., Hercules, CA, USA). Real-Time One-Step RT-PCR reactions were performed using $250 \mathrm{ng}$ of RNA and the QuantiTect Probe RT-PCR kit (Qiagen, Hilden, Germany) in a final volume of $25 \mu \mathrm{L}$ with primers and fluorescent probe concentrations of $0.8 \mu \mathrm{M}$ and $0.2 \mu \mathrm{M}$ for ABPV, CBPV, SBV and BQCV, respectively, and $0.35 \mu \mathrm{M}$ and $0.1 \mu \mathrm{M}$ for DWV-A and $1.2 \mu \mathrm{M}$ and $0.4 \mu \mathrm{M}$ for DWV-B. After the initial reverse transcription of RNA at $50^{\circ} \mathrm{C}$ for $30 \mathrm{~min}$, the amplification profile consisted of a denaturation step at $95^{\circ} \mathrm{C}$ for $10 \mathrm{~min}$ following by 40 cycles consisting of denaturation at $95^{\circ} \mathrm{C}$ for $15 \mathrm{~s}$ and annealing/extension at $60^{\circ} \mathrm{C}$ for $1 \mathrm{~min}$.

For IAPV and KBV detection, the RT-PCR was performed using the One-step RT-PCR kit (Qiagen, Hilden, Germany) on Veriti ${ }^{\mathrm{TM}}$ 96-Well Thermal Cycler (Applied Biosystems ${ }^{\mathrm{TM}}$, Waltham, MA, USA) in a final volume of $50 \mu \mathrm{L}$ containing $250 \mathrm{ng}$ of RNA and $0.4 \mu \mathrm{M}$ of each primers. PCR products ( $767 \mathrm{bp}$ for IAPV and 659 for KBV) were analysed by capillary electrophoresis on LabChip GX Touch $\mathrm{HT}^{\circledR}$ (Perkin Elmer, Waltham, MA, USA).

Negative and positive controls were included in each PCR. The references of all primers and probes used are reported in Table 1.

\subsection{Varroa Mite}

For the detection of DWV-A and DWV-B in the Varroa samples, a pool of at least 2 specimens per hive was homogenized by Tissue Lyser II (Qiagen, Hilden, Germany) in the presence of a $5 \mathrm{~mm}$ stainless steel beads. Total RNA was extracted using the RNA Isolation-NucleoSpin RNA kit (Macherey-Nagel, Düren, Germany) according to the manufacturer's instructions. Samples were analysed for DWV-A and DWV-B using primers, probes and amplification conditions used for the detection of the same viruses in bees (Table 1).

\subsection{Statistical Analysis}

All statistical analyses were performed using the STATA 17.0 (Stata Corp LLC. College Station, TX, USA) software, and Fisher Exact Test was carried out to determine if there was any association between the pathogens found. It was considered statistically significant if $p$-value $<\alpha$ adjusted with the number of possible comparisons for each pathogen with other pathogens with which it is possible to calculate the test (pathogens with all positive or negative samples excluded). A $5 \%$ level of significance was considered. Main statistical measures, such as median, have been calculated for the quantitative variable number of co-infection, and stratified for the landscape (plain, hills, and mountains).

\section{Results}

The prevalence of the honey bee pathogens is shown in Figure 2.

\subsection{Nosema spp.}

All the samples analysed in 2020 and 2021 were negative for N. apis. In the first year, of sampling the overall prevalence in all the hives tested for N. ceranae was $71.3 \%$, while in the second year, a slight decrease of $N$. ceranae positive hives was observed with an overall value of $64.4 \%$. In 2020, only one apiary (A) had all the hives negative for Nosema spp., while in four apiaries (B, E, H, I) all the hives resulted positive for this pathogen. In 2021, $N$. ceranae positive samples were found in all the apiaries with an occurrence ranging between $10 \%$ (apiary A) and 100\% (apiaries C, D, I). In regards to the N. ceranae infection rate, expressed as the number of $N$. ceranae spores per bee, the mean value per apiary was between $3.43 \times 10^{5}$ (apiary F) and $1.32 \times 10^{7}$ (apiary I) in 2020, while in 2021, it lowered to between $2.97 \times 10^{5}$ (apiary B) and $3.42 \times 10^{6}$ (apiary D). The data are shown in Figure 2 . 

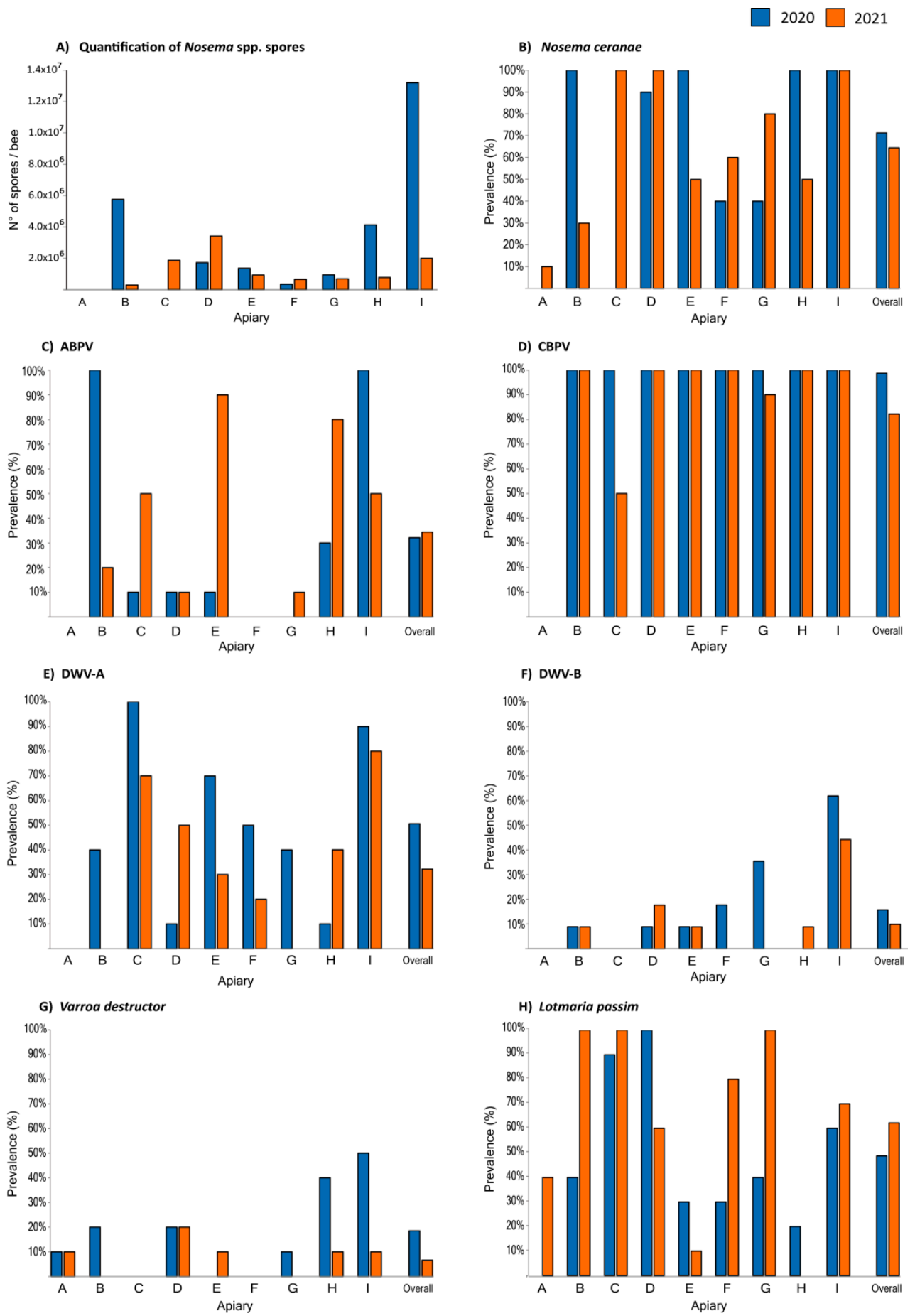

Figure 2. Number of Nosema spp. spores and overall pathogens' prevalence in sampled apiaries (from A to I). Panel (A): mean number of Nosema spp. spores per bee, detected in the sampled apiaries both in 2020 (blue bars) and 2021 (orange bars), is shown. Panels (B-H): frequencies (in percentage) of N. ceranae (B), ABPV (C), CBPV (D), DWV-A (E), DWV-B (F), V. destructor (G) and L. passim (H), detected in the sampled apiaries and in the overall population both in 2020 (blue bars) and 2021 (orange bars), are presented. N. apis, IAPV and KBV prevalence are not shown because all the analysed samples were negative. C. mellificae prevalence is not shown because positive honey bees were found only in one hive of apiary B in 2020. SBV prevalence is not shown because all the analysed samples resulted positive. BQCV prevalence is not shown because all the analysed samples resulted positive in 2020, and $97.8 \%$ of all hives (only two hives in apiary A were negative) resulted positive in 2021. 


\subsection{Lotmaria passim and Crithidia mellificae}

In both years of the study, L. passim was detected in almost all of the apiaries analysed with an overall positivity rate of $48.8 \%$ in 2020, while an increase was observed in 2021 with an overall value of $62.2 \%$. In 2020, only one apiary (D) had $100 \%$ L. passim positive hives, while in 2021, the number of apiaries with all the hives positive has increased to three (B, C, G). Concerning C. mellificae, it was detected only in one hive of the apiary B in 2020, while in 2021 no positive hives were found.

\subsection{Viruses}

In general, virus occurrence was higher in 2020 than in 2021. Of the eight viral pathogens tested, KBV and IAPV were not detected in any of the apiaries in both years. SBV and BQCV were the most prevalent viruses detected in honey bees $(100 \%$ of the apiaries) in 2020, with a very slight overall decrease in 2021 as regards BQCV $(97.8 \%)$. The other viruses (ABPV, CBPV, DWV-A and DWV-B) affected in different percentages the analysed apiaries (Figure 2). In 2020, the overall prevalence was $32.1 \%$ for ABPV, 98.8\% for CBPV, 50.6\% and $17.8 \%$ for DWV-A and DWV-B, respectively. In 2021, viral occurrences observed more or less reflected the trend of the previous year: $34.4 \%$ for ABPV, $82.2 \%$ for CBPV, $32.2 \%$ for DWV-A and $12.2 \%$ for DWV-B.

\subsection{Varroa Destructor Mite}

From the information provided by beekeepers, all the colonies were treated against Varroa mite infestation in the previous autumn/winter season (2019 and 2020) by means of oxalic acid-based veterinary medicines. In 2020, $V$. destructor was detected in six out of nine apiaries (A, B, D, G, H, I) with an overall prevalence of $18.5 \%$. Few specimens were found in four apiaries (A, B, D, G), while in the other ones (H and I, located in the hills) the number of specimens varied between 10 and 28. During 2021, Varroa was found in five out of nine apiaries (A, D, E, H, I), with an overall prevalence of $6.7 \%$, and only in the apiary A (located in the mountains) the number of specimens was more than three $(\mathrm{N}=18)$. The correlation between the presence of $V$. destructor and the DWV variants was investigated in the apiaries where the number of specimens was equal or more than three: in 2020, in apiaries D, H, I; in 2021, in apiaries A and D. None of the analysed Varroa specimens tested positive for DWV-A and DWV-B in the two years of sampling.

\subsection{Associations between Pathogen Occurrences}

Simultaneous multiple infections with several combinations of different pathogens have been detected in several hives from the nine apiaries (Figure 3).

In 2020, honey bees infected by three different combinations of pathogens were found in $3.7 \%$ of the hives, while co-infections with several combinations of four or five or more than five different pathogens were found in $21 \%, 37 \%$ and $38.3 \%$ of the honey bee samples, respectively. The most detected co-infections in 2020 were due to the simultaneous presence of: L. passim + CBPV + DWV-A + SBV + BQCV in the $12.3 \%$ of the hives; $N$. ceranae + L. passim + CBPV + SBV + BQCV in the $11.1 \%$ of the hives; $N$. ceranae + CBPV + SBV + BQCV in the $9.9 \%$ of the hives.

In 2021, only the $5.6 \%$ of the hives were co-infected with only two pathogens (SBV and $\mathrm{BQCV}$ ), while three or four or five different pathogens in several combinations were simultaneously found in $6.7 \%, 21.1 \%$ and $34.4 \%$ of colonies, respectively. Finally, more than five pathogens were present in $32.2 \%$ of honey bee samples. The most detected co-infections in 2021 were due to the simultaneous presence of N. ceranae + L. passim + CBPV + SBV + BQCV in the $18.9 \%$ of the hives and L. passim + CBPV + SBV + BQCV in the $8.9 \%$ of the hives. Statistical analyses showed that in both years of sampling the combination $N$. ceranae + L. passim + CBPV + SBV + BQCV is present in more than $10 \%$ of the hives analysed, with an increase in 2021 compared to 2020. However, in 2020 a significant association only between the presence of ABPV and N. ceranae ( $p=0.000)$ was found; in 2021, the significant pathogen associations were three and precisely between APV and L. passim $(p=0.004)$, 
DWV-A and DWV-B $(p=0.004)$ and DW-A and N. ceranae ( $p=0.010$ significant at a $10 \%$ level). No other significant associations were observed in both years.

A)

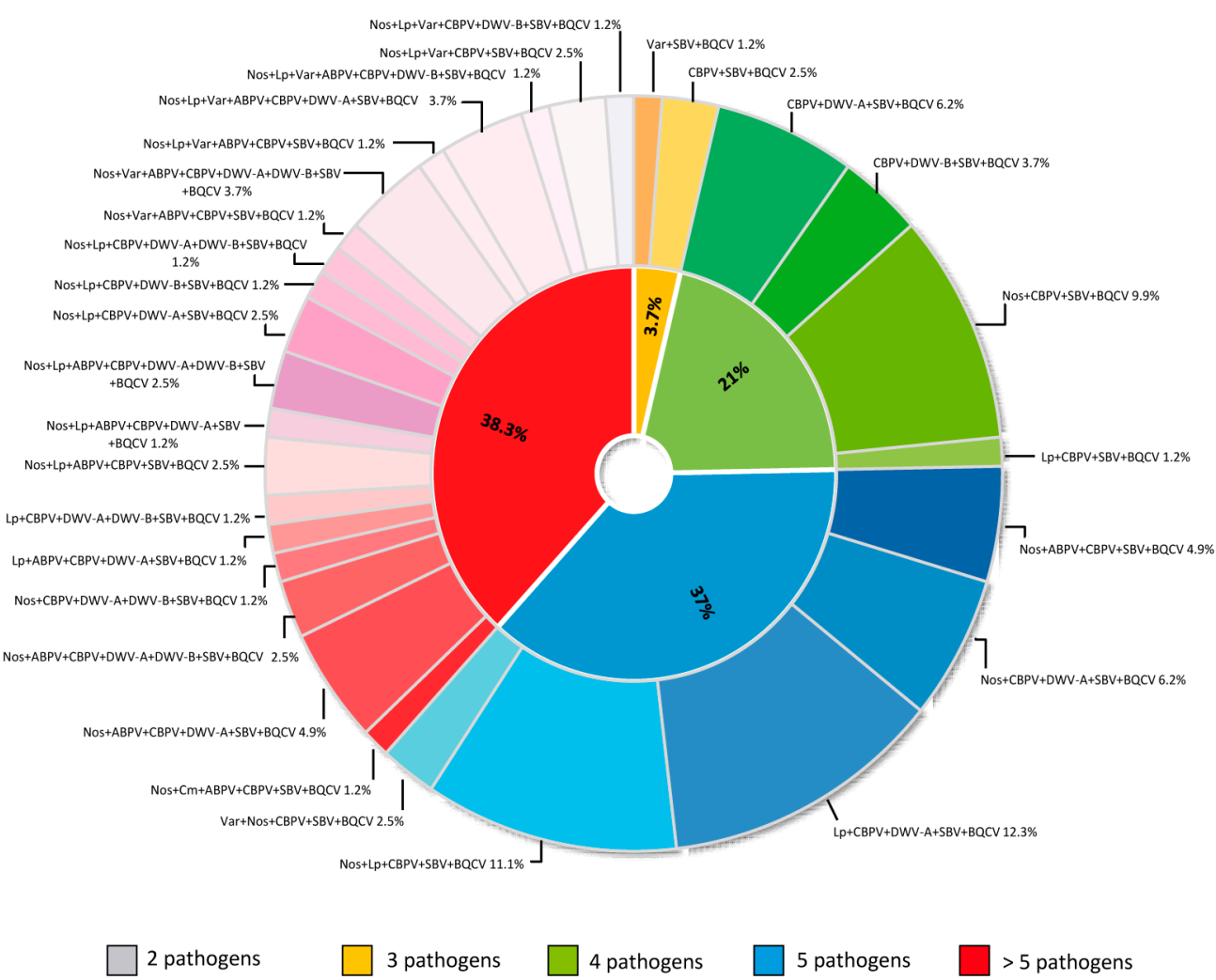

B)

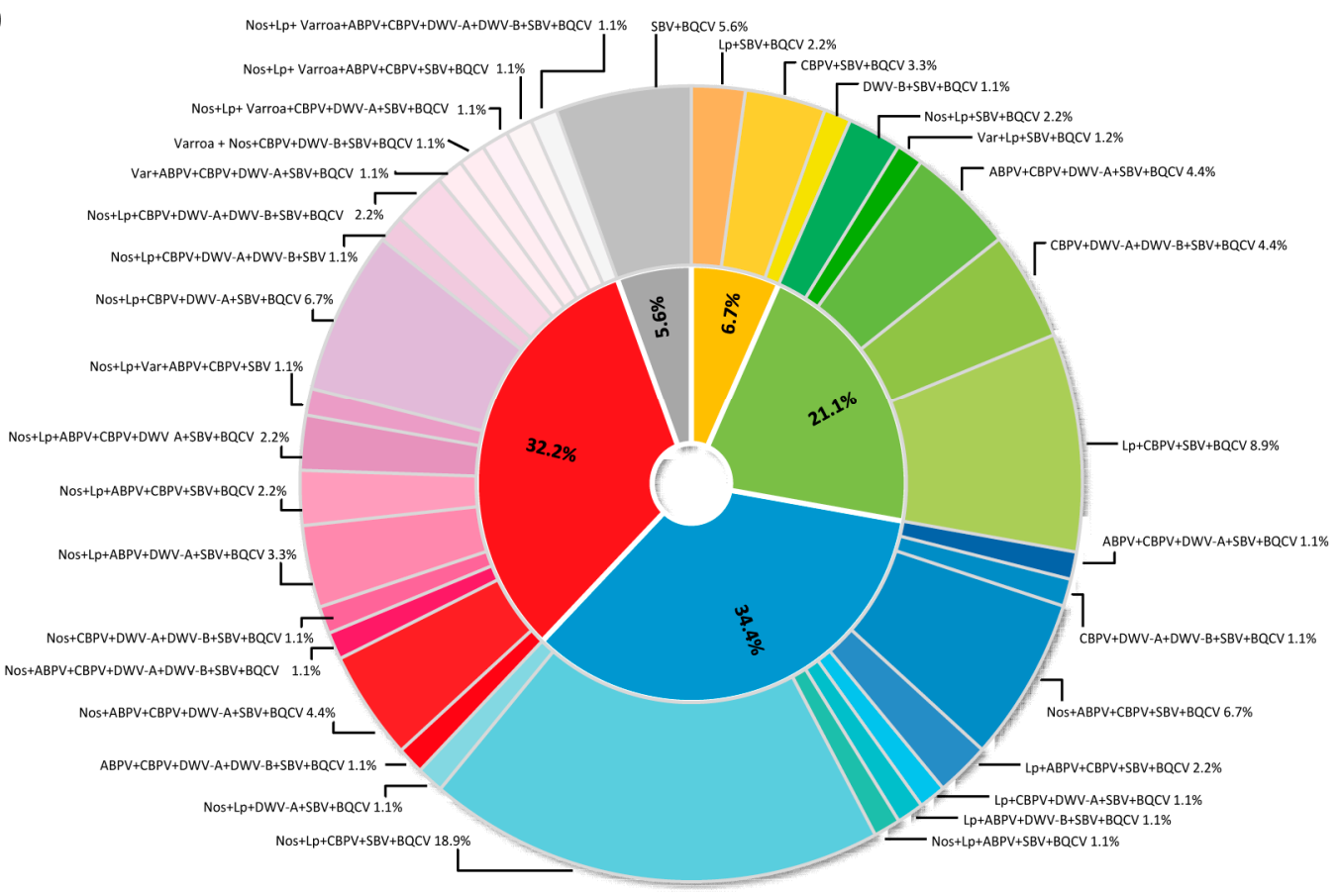

Figure 3. Percentage and type of multiple infections found in all nine apiaries in 2020 (A) and 2021 (B). Co-infections with 2 pathogens are shown in the shades of grey, with 3 pathogens in the shades of yellow, with 4 pathogens in the shades of green, with 5 pathogens in the shades of blue, and with 6 pathogens or more in the shades of red. 
Median values of the number of co-infections have been calculated and stratified for the landscape (plain, hills, and mountains). From the data obtained in 2020, a median decrease from the plain (5.3) and hills (5.7) to the mountains (3.0) could be observed. Similarly, in 2021, co-infections detected in the mountain environment had a lower median value (2.7) than those of the plain (5.1) and hills (5.3).

\section{Discussion}

In recent years, numerous events of honey bee mortality or beehive depopulation have been reported in Europe and other countries around the world. Several causes have been identified as responsible stressors, in particular, the presence of different pathogens and parasites that can act individually or in synergy. During the last years, monitoring plans have, therefore, been set up at national level to know the health status of bee colonies and, in Italy, the ApeNet (2009-2010) and BeeNet (2011-2014) projects and other studies were established to monitor hundreds of apiaries distributed over almost the entire Italian territory in order to assess the health of $A$. mellifera $[28,72,73]$.

The resumption of activity in spring is an important moment for the development of the bee colony and is influenced by both the interventions carried out by beekeepers in the previous autumn and winter seasons and the pathogens presence in the hives. In order to collect information on the health status of nine apiaries situated in the Veneto region, in northeast of Italy, we investigated in spring the presence, distribution and prevalence of eight viruses (ABPV, CBPV, DWV-A, DWV-B, SBV, BQCV, IAPV and KBV), fungi (Nosema spp.), trypanosomatids (L. passim and C. mellificae) and Varroa mite.

A total of ten pathogens (N. ceranae, L. passim, C. mellificae, ABPV, CBPV, BQCV, SBV, DWV-A, DWV-B, V. destructor) were found in spring 2020 and 2021, even if all the honey bees analysed for each year showed no clinical symptoms of disease.

BQCV and SBV were the most prevalent pathogens over the two years in all the apiaries investigated (Figure 2). This not only confirm what has already been shown in studies previously conducted in many European countries as Italy [28], Austria [74], Belgium [75,76], Germany [1], Spain [58], Denmark [77] and France [78], but the infection levels of these viruses in Veneto was higher than the level reported in the literature. SBV is the most widely distributed of all honey bee viruses [36]. As reported by Morawetz et al. [79], high prevalence of SBV is frequent in European honey bee colonies, particularly in spring and summer, when the colony is growing most rapidly and large numbers of larvae are available [78], and it is generally higher both in symptomatic and asymptomatic honey bees [80]. The BQCV infection mainly affects queen larvae and pupae instead and has the highest incidence in spring and early summer; BQCV infected adult bees normally do not exhibit outward disease symptoms [78]. Moreover, several previous reports linked BQCV disease outbreaks with infection of $N$. apis $[74,78,81]$ and $N$. ceranae $[25,82-85]$, suggesting that these pathogens can act synergistically. Even if many apiaries analysed in this study showed co-infections of BQCV with $N$. ceranae, no statistically significant association was found, since BQCV infection was always present in almost all the hives.

As already mentioned above, $N$. ceranae spores were detected, even in considerable number, in several honey bee colonies while $N$. apis was never found. The overall prevalence values of N. ceranae, $71.3 \%$ in 2020 and $64.4 \%$ in 2021, respectively, confirmed the higher diffusion of $N$. ceranae previously reported in different Italian regions [86-88], in other European countries [53,58,89,90] and worldwide [51,63,91-93]. The high prevalence of $N$. ceranae together with the absence of $N$. apis infection corroborates the findings of other authors that N. ceranae is definitely spread in Italy and has basically replaced N. apis [86]. The hives of apiary A were the only colonies with the lower levels of N. ceranae infection, but while in 2020 only one hive has been analysed, since the beekeeper was unable to sample a sufficient number of bees, in 2021 only $10 \%$ of the hives were positive to N. ceranae. All the hives of apiary C tested negative to N. ceranae in 2020, whereas in 2021 all of them were positive. As regards the others apiaries, B, E and $\mathrm{H}$, they halved the prevalence of $N$. ceranae from 2020 to 2021, while the apiaries D, F and G showed an increase in the 
number of positive colonies. Only apiary I kept at $100 \%$ N. ceranae prevalence in both years. Moreover, the mean value of the number of $N$. ceranae spores per bee per apiary was higher in 2020 than in 2021. Given that N. ceranae could negatively affect honey bee health causing weakening and depression of the immune system [94] of insects, favouring viral infections or under certain conditions bring the colony to collapse [95], the presence of a significant association between $N$. ceranae and other pathogens was analysed in this study. The data obtained from statistical analysis of the observed infections highlighted particular significant associations between $N$. ceranae with ABPV and the DWV-A variant. In addition, $N$. ceranae infected colonies tested positive to SBV and/or CBPV and/or BQCV, supporting the fact that $N$. ceranae occurrence could increase honey bees susceptibility to other pathogens [65].

Besides N. ceranae, the prevalence of trypanosomatid L. passim was very high in both years: indeed more than half of the analysed hives tested positive to L. passim (51.3\% in 2020 and 62.2\% in 2021, respectively) and in 2021 its occurrence increased in all apiaries, except for apiaries D, E and H, confirming its greater diffusion in the world [48]. Although many researches have demonstrated that L. passim can be present with other pathogens too and especially a relationship between $N$. ceranae and L. passim have been reported [96] as well as between L. passim and viruses, making plausible synergistic effects [51], the results here reported did not show a significant association of L. passim with $N$. ceranae, but it was significantly associated with ABPV. How L. passim could influence the occurrence and virulence of the other pathogens in the host is unknown and requires further studies. The other protozoan C. mellificae, recently correlated with colony losses in the USA and Belgium, was often detected in association with $N$. ceranae $[51,53,97]$. However, in the present study it was found only in one hive of the apiary B in 2020.

Several studies reported interactions, sometimes controversial, between N. ceranae and DWV virus $[27,96,98]$. Our statistical analysis confirms a significant association between $N$. ceranae and DWV-A variant in both years of sampling. DWV was described as the most prevalent virus in Europe [2] and it has been suggested that its widespread was most probably due to the Varroa mites infestation [99], which could be a new viral transmission route, in particular in summer and autumn than in spring [78,79], causing elevated viral loads [45,100,101] and selecting for DWV variants [102]. About these variants, three were mainly reported, each one with a different prevalence [42]. DWV-A was initially the dominant genotype, but over the years, DWV-B prevalence has increased and numerous studies reported now DWV-B as the dominant variant in Europe [103]. DWV-B has been considered a more virulent variant than the DWV-A genotype [41] and mostly associated to Varroa mite infestation, whose transmission could exert strong selection on DWV genomes [104], favouring DWV-B. However, little is still known about the prevalence of DWV variants in Italy. The data provided by this study reported overall prevalence values of DWV-A variant ranging between 50.6\% (2020) and 32.2\% (2021) of hives, while for DWV-B between $17.8 \%$ (2020) and 12.2\% (2021). In particular, apiary I kept high levels of DWV infection in both years, and this apiary was the one in which most of all investigated pathogens were found. Except for the apiary A, DWV-A variant was found in 2020 in all the apiaries, while for DWV-B variant apiaries A, C and $\mathrm{H}$ resulted negative. Interestingly, the prevalence of DWV-A decreased in 2021 in all the apiaries found positive the previous year, except in apiary A, which still remained negative, and apiaries D and H. DWV-B, instead, behaved in a heterogeneous way among all the apiaries (except in apiaries $A$ and $C$, with no positive samples found in both years) with an overall slight decrease from 2020 to 2021. Although a strong connection between DWV-B and Varroa was previously demonstrated $[44,105,106]$, no significant association was found in this survey even if the overall prevalence of Varroa in the sampled apiaries declined in 2021 similarly to DWV-B.

Regarding the other viruses investigated in this study, IAPV and KBV were not detected, in accordance with their distribution, which is predominant in Israel, Australia, Asia and USA and less prevalent in Europe [2,22,28,33,65,78,94], while ABPV and CBPV were observed in almost all the nine apiaries. As reported by Berényi et al. [74], since 
$\mathrm{ABPV}$, IAPV and KBV share a high level of genetic similarity (the high virulent "AKI complex"), it is supposed that these viruses derive from a common ancestor and then evolved and distributed independently in different geographical areas around the world. This hypothesis is also reinforced by the fact that in Veneto region and in Italy in general, as well as in the near Austria, Slovenia and Croatia [74,107,108], most of the reported cases identified ABPV as the predominant viral species instead of KBV or IAPV. The overall prevalence of ABPV found in Veneto region was between 32.1\% (2020) and 34.4\% (2021), but not in all the apiaries analysed the value increased from one year to the next: if indeed in apiaries $\mathrm{C}, \mathrm{E}, \mathrm{F}$ and $\mathrm{G}$ the $\mathrm{ABPV}$ positive hives increased with different percentages, in the apiaries $B$ and I there was a decrease of more than half of infected colonies, and in the apiaries $\mathrm{A}$ and $\mathrm{F}$ the virus has never been detected. It is known that this virus is quite commonly found in apparently healthy families and it plays a decisive role in the sudden and asymptomatic collapse of the colonies, especially in winter. Moreover, it was supposed that ABPV infection, like DWV, might be spread to honey bees by $V$. destructor, but the presence of very low infested colonies in the apiaries analysed suggested that these viruses could replicate and transmit through other ways.

CBPV occurred in eight out of nine apiaries (the mountain apiary A always tested negative in both years) with an overall prevalence of $98.8 \%$ in 2020 and $82.2 \%$ in 2021 . Although CBPV is widespread in honey bees worldwide and probably due to intensive commercial exchange of insects and hive materials [81], these values were very high compared to what was reported in other European countries, such as France $(28 \%)$, Slovenia (18.3\%), Austria (9\%), Czech Republic (8\%) and Denmark (4\%) [74,78,90,108,109], even if the colonies considered in these studies, unlike ours, showed clinical symptoms of viral infection. The appearance of the clinical form of the disease is linked to episodes of overcrowding in the hive, especially in spring or summer, in the event of persistent adverse weather conditions, and/or the consumption of honeydew. No data about this kind of event resulted from the questionnaires provided by the beekeepers, and the honey bees did not show any symptom of paralysis or malaise.

Finally, different pathogens prevalence and distribution were observed when comparing the different landscapes (plain, hill, and mountain) where the apiaries were located. From the data obtained in 2020, a median decrease in the number of coinfections from the plain (5.3) and hills (5.7) to the mountains (3.0) could be observed. However, the number of co-infections in the honey bees reared in the mountain area derived from the analysis of only one hive of the apiary A. For this reason, the three locations could not be evaluated from a statistical point of view. A similar consideration could also be made for 2021 sampling, where co-infections detected in the mountain environment had a lower median value (2.7) than those of the plain (5.1) and hills (5.3), but since they resulted from a single apiary, they were not very informative and would probably need at least one other apiary in the same geographic area to make the data more robust. However, since the treatments against Varroa carried out on the colonies in the previous autumn/winter season (2019 and 2020) were the same, the environmental conditions of the mountain (lower apiary density $/ \mathrm{km}^{2}$ ) may probably have reduced contacts among honey bees of different apiaries and/or drifting, and hence the spread of infectious agents. On the other hand, with the intensive trade and transport of bee colonies, queens and hives from place to place or in general, the application or not of best beekeeping practices could vary the transmission and spread of these pathogens between apiaries.

\section{Conclusions}

The global decline in the bee population poses a serious ecological and economic threat: honey bees are critically important to the environment, supporting biodiversity with pollination for a wide range of crops and wild plants, and they also contribute to human wealth and well-being. The impact of anthropogenic activities is increasingly reducing their number and vigour worldwide, in particular by reducing their resistance to parasites (viruses, bacteria, fungi, mites) and consequently their efficiency in pollination and 
production of honey. The current descriptive study showed that honey bee hives distributed in several apiaries of the Veneto region were infected with more pathogens. Among these, the most prevalent were BQCV, SBV and CBPV viruses followed by N. ceranae and $L$. passim, which are currently distributed worldwide. Studies like this, even if conducted on a regional scale, will help advance our understanding of pathogen's behaviour and focus on the effects of the interactions between them and bee colony. In this way, keeping monitor bee colonies not only locally or nationally but globally, we could promptly intervene on potential problems that could arise and combat honey bee diseases taking in appropriate consideration the environment and the consumer's health.

Author Contributions: Conceptualization, A.G. and F.M.; methodology, A.G., F.M., F.B. and L.Z.; software, M.T.; validation, A.G., F.B. and L.Z.; investigation, M.C., R.C., F.B., L.Z., L.T. and L.B.; data curation, F.B. and L.Z.; writing—original draft preparation: F.B., L.Z., A.G. and F.M.; writing—review and editing, F.B., L.Z., A.G. and F.M.; supervision, F.M.; project administration, A.G. and F.M.; funding acquisition, F.M. All authors have read and agreed to the published version of the manuscript.

Funding: This study was founded by the Veneto region (DGR n. 1158 of 6 August 2019 and n. 1079 of 6 August 2020, action F2) through Regulation (EU) No 1308/2013 of the European Parliament and of the Council of 17 December 2013 establishing a common organization of the markets in agricultural products and repealing Council Regulations (EEC) No 922/72, (EEC) No 234/79, (EC) No 1037/2001 and (EC) No 1234/2007 and the Italian Ministry of Health, RC IZSVE 09/20.

Institutional Review Board Statement: Not applicable.

Informed Consent Statement: Not applicable.

Data Availability Statement: Data are available from the authors provided General Data Protection Regulation is guaranteed.

Acknowledgments: Ennio Matterazzo and Luciana Barzon for the technical and administrative support in the organization of this work, and Claudia Casarotto for preparing the map are kindly acknowledged. We wish to thank the beekeepers and their associations who made their apiaries available for this study.

Conflicts of Interest: The authors declare no conflict of interest. The funders had no role in the design of the study; in the collection, analyses, or interpretation of data; in the writing of the manuscript, or in the decision to publish the results.

\section{References}

1. Genersch, E. Honey bee pathology: Current threats to honey bees and beekeeping. Appl. Microbiol. Biotechnol. $2010,87,87-97$. [CrossRef]

2. Genersch, E.; Evans, J.D.; Fries, I. Honey bee disease overview. J. Invertebr. Pathol. 2010, 103, S2-S4. [CrossRef] [PubMed]

3. McMenamin, A.J.; Brutscher, L.M.; Glenny, W.; Flenniken, M.L. Abiotic and biotic factors affecting the replication and pathogenicity of bee viruses. Curr. Opin. Insect Sci. 2016, 16, 14-21. [CrossRef]

4. Regulation (EU) No 1308/2013 of the European Parliament and of the Council of 17 December 2013 Establishing a Common Organisation of the Markets in Agricultural Products and Repealing Council Regulations (EEC) No 922/72, (EEC) No 234/79, (EC) No 1037/2001 and (EC) No 1234/2007. 2013. Available online: https:/ / eur-lex.europa.eu/eli/reg/2013/1308/oj (accessed on 20 January 2022).

5. Ellis, J.D.; Munn, P.A. The worldwide health status of honey bees. Bee World 2005, 86, 88-101. [CrossRef]

6. Beaurepaire, A.; Piot, N.; Doublet, V.; Antunez, K.; Campbell, E.; Chantawannakul, P.; Chejanovsky, N.; Gajda, A.; Heerman, M.; Panziera, D.; et al. Diversity and Global Distribution of Viruses of the Western Honey Bee, Apis mellifera. Insects 2020, 11, 239. [CrossRef]

7. Steinhauer, N.; Kulhanek, K.; Antúnez, K.; Human, H.; Chantawannakul, P.; Chauzat, M.P.; van Engelsdorp, D. Drivers of colony losses. Curr. Opin. Insect Sci. 2018, 26, 142-148. [CrossRef]

8. Nanetti, A.; Bortolotti, L.; Cilia, G. Pathogens Spillover from Honey Bees to Other Arthropods. Pathogens 2021, 10, 1044. [CrossRef]

9. Alaux, C.; Folschweiller, M.; McDonnell, C.; Beslay, D.; Cousin, M.; Dussaubat, C.; Brunet, J.L.; Le Conte, Y. Pathological effects of the microsporidium Nosema ceranae on honey bee queen physiology (Apis mellifera). J. Invertebr. Pathol. 2011, 106, 380-385. [CrossRef]

10. Fries, I. Nosema ceranae in European honey bees (Apis mellifera). J. Invertebr. Pathol. 2010, 103 (Suppl. 1), 73. [CrossRef] 
11. Bromenshenk, J.J.; Henderson, C.B.; Wick, C.H.; Stanford, M.F.; Zulich, A.W.; Jabbour, R.E.; Deshpande, S.V.; McCubbin, P.E.; Seccomb, R.A.; Welch, P.M.; et al. Iridovirus and microsporidian linked to honey bee colony decline. PLoS ONE 2010, 5, e13181. [CrossRef]

12. Anderson, D.L. Pests and Pathogens of the Honeybee (Apis mellifera L.) in Fiji. J. Apic. Res. 1990, 29, 53-59. [CrossRef]

13. Benjeddou, M.; Leat, N.; Allsopp, M.; Davison, S. Detection of acute bee paralysis virus and black queen cell virus from honeybees by reverse transcriptase pcr. Appl. Environ. Microbiol. 2001, 67, 2384-2387. [CrossRef]

14. Evans, J.D. Genetic evidence for coinfection of honey bees by acute bee paralysis and Kashmir bee viruses. J. Invertebr. Pathol. 2001, 78, 189-193. [CrossRef] [PubMed]

15. Chen, Y.; Zhao, Y.; Hammond, J.; Hsu, H.T.; Evans, J.; Feldlaufer, M. Multiple virus infections in the honey bee and genome divergence of honey bee viruses. J. Invertebr. Pathol. 2004, 87, 84-93. [CrossRef] [PubMed]

16. Chen, Y.; Pettis, J.S.; Feldlaufer, M.F. Detection of multiple viruses in queens of the honey bee Apis mellifera L. J. Invertebr. Pathol. 2005, 90, 118-121. [CrossRef]

17. Carrillo-Tripp, J.; Dolezal, A.G.; Goblirsch, M.J.; Miller, W.A.; Toth, A.L.; Bonning, B.C. In Vivo and in vitro infection dynamics of honey bee viruses. Sci. Rep. 2016, 6, 22265. [CrossRef]

18. Christian, P.D.; Scotti, P.D. Picornalike Viruses of Insects. In The Insect Viruses; Miller, L.K., Ball, L.A., Eds.; Springer: Boston, MA, USA, 1998; pp. 301-336.

19. Valles, S.M.; Strong, C.A.; Hashimoto, Y. A new positive-strand RNA virus with unique genome characteristics from the red imported fire ant, Solenopsis invicta. Virology 2007, 365, 457-463. [CrossRef]

20. Ribière, M.; Ball, B.; Aubert, M. Natural history and geographical distribution of honey bee viruses. In Virology and the Honey Bee; Aubert, M., Ball, B., Fries, I., Moritz, R., Milani, N., Bernardinelli, I., Eds.; European Communities: Luxembourg, 2008 ; pp. 15-84.

21. Bailey, L.; Gibbs, A.J.; Woods, R.D. Two viruses from adult honey bees (Apis mellifera Linnaeus). Virology 1963, 21, $390-395$. [CrossRef]

22. Maori, E.; Lavi, S.; Mozes-Koch, R.; Gantman, Y.; Peretz, Y.; Edelbaum, O.; Tanne, E.; Sela, I. Isolation and characterization of Israeli acute paralysis virus, a dicistrovirus affecting honeybees in Israel: Evidence for diversity due to intra- and inter-species recombination. J. Gen. Virol. 2007, 88, 3428-3438. [CrossRef]

23. Shen, M.; Cui, L.; Ostiguy, N.; Cox-Foster, D. Intricate transmission routes and interactions between picorna-like viruses (Kashmir bee virus and sacbrood virus) with the honeybee host and the parasitic varroa mite. J. Gen. Virol. 2005, 86, 2281-2289. [CrossRef]

24. Bailey, L.; Woods, R.D. Two more small RNA viruses from honey bees and further observations on sacbrood and acute beeparalysis viruses. J. Gen. Virol. 1977, 37, 175-182. [CrossRef]

25. Doublet, V.; Labarussias, M.; de Miranda, J.R.; Moritz, R.F.; Paxton, R.J. Bees under stress: Sublethal doses of a neonicotinoid pesticide and pathogens interact to elevate honey bee mortality across the life cycle. Environ. Microbiol. 2015, 17, 969-983. [CrossRef] [PubMed]

26. Olivier, V.; Blanchard, P.; Chaouch, S.; Lallemand, P.; Schurr, F.; Celle, O.; Dubois, E.; Tordo, N.; Thiéry, R.; Houlgatte, R.; et al. Molecular characterisation and phylogenetic analysis of Chronic bee paralysis virus, a honey bee virus. Virus Res. 2008, 132, 59-68. [CrossRef] [PubMed]

27. Traynor, K.S.; Rennich, K.; Forsgren, E.; Rose, R.; Pettis, J.; Kunkel, G.; Madella, S.; Evans, J.; Lopez, D.; van Engelsdorp, D. Multiyear survey targeting disease incidence in US honey bees. Apidologie 2016, 47, 325-347. [CrossRef]

28. Porrini, C.; Mutinelli, F.; Bortolotti, L.; Granato, A.; Laurenson, L.; Roberts, K.; Gallina, A.; Silvester, N.; Medrzycki, P.; Renzi, T.; et al. The Status of Honey Bee Health in Italy: Results from the Nationwide Bee Monitoring Network. PLoS ONE 2016, 11, e0155411. [CrossRef]

29. Li, B.; Deng, S.; Yang, D.; Hou, C.; Diao, Q. Complete sequences of the RNA 1 and RNA 2 segments of chronic bee paralysis virus strain CBPV-BJ detected in China. Arch. Virol. 2017, 162, 2451-2456. [CrossRef]

30. Bailey, L. Recent research on honeybee viruses. Bee World 1975, 56, 55-64. [CrossRef]

31. Ribière, M.; Olivier, V.; Blanchard, P. Chronic bee paralysis: A disease and a virus like no other? J. Invertebr. Pathol. 2010, 103 (Suppl. 1), 120. [CrossRef]

32. Lanzi, G.; de Miranda, J.R.; Boniotti, M.B.; Cameron, C.E.; Lavazza, A.; Capucci, L.; Camazine, S.M.; Rossi, C. Molecular and biological characterization of deformed wing virus of honeybees (Apis mellifera L.). J. Virol. 2006, 80, 4998-5009. [CrossRef]

33. De Miranda, J.R.; Genersch, E. Deformed wing virus. J. Invertebr. Pathol. 2010, 103 (Suppl. 1), 48. [CrossRef]

34. Bailey, L. The multiplication and spread of sacbrood virus of bees. Ann. Appl. Biol. 1969, 63, 483-491. [CrossRef] [PubMed]

35. Bailey, L.; Gibbs, A.J.; Woods, R.D. Sacbrood virus of the larval honey bee (Apis mellifera linnaeus). Virology 1964, 23, 425-429. [CrossRef]

36. Chen, Y.P.; Siede, R. Honey bee viruses. Adv. Virus Res. 2007, 70, 33-80. [PubMed]

37. Wang, D.; Mofller, F.E. The Division of Labor and Queen Attendance Behavior of Nosema-Infected Worker Honey Bees. J. Econ. Entomol. 1970, 63, 1539-1541. [CrossRef]

38. Bailey, L.; Fernando, E.F.W. Effects of sacbrood virus on adult honey-bees. Ann. Appl. Biol. 1972, 72, 27-35. [CrossRef]

39. Yue, C.; Genersch, E. RT-PCR analysis of Deformed wing virus in honeybees (Apis mellifera) and mites (Varroa destructor). J. Gen. Virol. 2005, 86, 3419-3424. [CrossRef]

40. Nordström, S. Distribution of deformed wing virus within honey bee (Apis mellifera) brood cells infested with the ectoparasitic mite Varroa destructor. Exp. Appl. Acarol. 2003, 29, 293-302. [CrossRef] 
41. McMahon, D.P.; Natsopoulou, M.E.; Doublet, V.; Fürst, M.; Weging, S.; Brown, M.J.F.; Gogol-Döring, A.; Paxton, R.J. Elevated virulence of an emerging viral genotype as a driver of honeybee loss. Proc. Royal Soc. B Biol. Sci. 2016, 283, 20160811. [CrossRef]

42. Mordecai, G.J.; Wilfert, L.; Martin, S.J.; Jones, I.M.; Schroeder, D.C. Diversity in a honey bee pathogen: First report of a third master variant of the Deformed Wing Virus quasispecies. ISME J. 2016, 10, 1264-1273. [CrossRef]

43. Ramsey, S.D.; Ochoa, R.; Bauchan, G.; Gulbronson, C.; Mowery, J.D.; Cohen, A.; Lim, D.; Joklik, J.; Cicero, J.M.; Ellis, J.D.; et al. Varroa destructor feeds primarily on honey bee fat body tissue and not hemolymph. Proc. Natl. Acad. Sci. USA 2019, 116, 1792. [CrossRef]

44. Rosenkranz, P.; Aumeier, P.; Ziegelmann, B. Biology and control of Varroa destructor. J. Invertebr. Pathol. 2009, 103 (Suppl. 1), 96. [CrossRef] [PubMed]

45. Nazzi, F.; Brown, S.P.; Annoscia, D.; Del Piccolo, F.; Di Prisco, G.; Varricchio, P.; Della Vedova, G.; Cattonaro, F.; Caprio, E.; Pennacchio, F. Synergistic parasite-pathogen interactions mediated by host immunity can drive the collapse of honeybee colonies. PLoS Pathog. 2012, 8, e1002735. [CrossRef]

46. Kang, Y.; Blanco, K.; Davis, T.; Wang, Y.; DeGrandi-Hoffman, G. Disease dynamics of honeybees with Varroa destructor as parasite and virus vector. Math. Biosci. 2016, 275, 71-92. [CrossRef] [PubMed]

47. De Miranda, J.; Cordoni, G.; Budge, G. The Acute bee paralysis virus-Kashmir bee virus-Israeli acute paralysis virus complex. J. Invertebr. Pathol. 2009, 103 (Suppl. 1), 30. [CrossRef] [PubMed]

48. Schwarz, R.S.; Bauchan, G.R.; Murphy, C.A.; Ravoet, J.; de Graaf, D.C.; Evans, J.D. Characterization of Two Species of Trypanosomatidae from the Honey Bee Apis mellifera: Crithidia mellificae Langridge and McGhee, and Lotmaria passim n. gen., n. sp. J. Eukaryot. Microbiol. 2015, 62, 567-583. [CrossRef] [PubMed]

49. Arismendi, N.; Caro, S.; Castro, M.P.; Vargas, M.; Riveros, G.; Venegas, T. Impact of Mixed Infections of Gut Parasites Lotmaria passim and Nosema ceranae on the Lifespan and Immune-related Biomarkers in Apis mellifera. Insects 2020, 11, 420. [CrossRef] [PubMed]

50. Langridge, D.F.; McGhee, R.B. Crithidia mellificae n. sp. an acidophilic trypanosomatid of the honey bee Apis mellifera. J. Protozool. 1967, 14, 485-487. [CrossRef]

51. Runckel, C.; Flenniken, M.L.; Engel, J.C.; Ruby, J.G.; Ganem, D.; Andino, R.; De Risi, J.L. Temporal Analysis of the Honey Bee Microbiome Reveals Four Novel Viruses and Seasonal Prevalence of Known Viruses, Nosema, and Crithidia. PLoS ONE 2011, 6, e20656. [CrossRef]

52. Cornman, R.S.; Tarpy, D.R.; Chen, Y.; Jeffreys, L.; Lopez, D.; Pettis, J.S.; van Engelsdorp, D.; Evans, J.D. Pathogen Webs in Collapsing Honey Bee Colonies. PLoS ONE 2012, 7, e43562. [CrossRef]

53. Ravoet, J.; Maharramov, J.; Meeus, I.; De Smet, L.; Wenseleers, T.; Smagghe, G.; de Graaf, D.C. Comprehensive Bee Pathogen Screening in Belgium Reveals Crithidia mellificae as a New Contributory Factor to Winter Mortality. PLoS ONE 2013, 8, e72443. [CrossRef]

54. Cepero, A.; Martín-Hernández, R.; Bartolomé, C.; Gómez-Moracho, T.; Barrios, L.; Bernal, J.; Teresa Martín, M.; Meana, A.; Higes, M. Passive laboratory surveillance in Spain: Pathogens as risk factors for honey bee colony collapse. J. Apic. Res. 2015, 54, 525-531. [CrossRef]

55. Schwarz, R.S.; Moran, N.A.; Evans, J.D. Early gut colonizers shape parasite susceptibility and microbiota composition in honey bee workers. Proc. Natl. Acad. Sci. USA 2016, 113, 9345. [CrossRef] [PubMed]

56. Vejnovic, B.; Stevanovic, J.; Schwarz, R.S.; Aleksic, N.; Mirilovic, M.; Jovanovic, N.M.; Stanimirovic, Z. Quantitative PCR assessment of Lotmaria passim in Apis mellifera colonies co-infected naturally with Nosema ceranae. J. Invertebr. Pathol. 2018, 151, 76-81. [CrossRef] [PubMed]

57. Stevanovic, J.; Schwarz, R.S.; Vejnovic, B.; Evans, J.D.; Irwin, R.E.; Glavinic, U.; Stanimirovic, Z. Species-specific diagnostics of Apis mellifera trypanosomatids: A nine-year survey (2007-2015) for trypanosomatids and microsporidians in Serbian honey bees. J. Invertebr. Pathol. 2016, 139, 6-11. [CrossRef] [PubMed]

58. Buendía-Abad, M.; Martín-Hernández, R.; Ornosa, C.; Barrios, L.; Bartolomé, C.; Higes, M. Epidemiological study of honeybee pathogens in Europe: The results of Castilla-La Mancha (Spain). Span. J. Agric. Res. 2018, 16, e0502. [CrossRef]

59. Xu, G.; Palmer-Young, E.; Skyrm, K.; Daly, T.; Sylvia, M.; Averill, A.; Rich, S. Triplex real-time PCR for detection of Crithidia mellificae and Lotmaria passim in honey bees. Parasitol. Res. 2018, 117, 623-628. [CrossRef] [PubMed]

60. Castelli, L.; Branchiccela, B.; Invernizzi, C.; Tomasco, I.; Basualdo, M.; Rodriguez, M.; Zunino, P.; Antúnez, K. Detection of Lotmaria passim in Africanized and European honey bees from Uruguay, Argentina and Chile. J. Invertebr. Pathol. 2018, 160 , 95-97. [CrossRef]

61. Van Engelsdorp, D.; Lengerich, E.; Spleen, A.; Dainat, B.; Cresswell, J.; Baylis, K.; Nguyen, B.K.; Soroker, V.; Underwood, R.; Human, H.; et al. Standard epidemiological methods to understand and improve Apis mellifera health. J. Apic. Res. 2013, 52, 1-16. [CrossRef]

62. OIE Manual of Diagnostic Tests and Vaccines for Terrestrial Animals 2021. Chapter 9.6. Infestation of Honey Bees with Varroa spp. (Varroosis) Article 9.6.1. Available online: https://www.oie.int/en/what-we-do/standards/codes-and-manuals/terrestrialcode-online-access / ?id=169\&L=1\&htmfile=chapitre_varroa_spp.htm (accessed on 20 January 2022).

63. Martín-Hernández, R.; Meana, A.; Prieto, L.; Salvador, A.M.; Garrido-Bailón, E.; Higes, M. Outcome of colonization of Apis mellifera by Nosema ceranae. Appl. Environ. Microbiol. 2007, 73, 6331-6338. [CrossRef] 
64. Bartolomé, C.; Buendía-Abad, M.; Benito, M.; De la Rua, P.; Ornosa, C.; Martín-Hernández, R.; Higes, M.; Maside, X. A new multiplex PCR protocol to detect mixed trypanosomatid infections in species of Apis and Bombus. J. Invertebr. Pathol. 2018, 154, 37-41. [CrossRef]

65. Cox-Foster, D.; Conlan, S.; Holmes, E.C.; Palacios, G.; Evans, J.D.; Moran, N.A.; Quan, P.; Briese, T.; Hornig, M.; Geiser, D.M. A metagenomic survey of microbes in honey bee colony collapse disorder. Science 2007, 318, 283-287. [CrossRef] [PubMed]

66. Carletto, J.; Aurélie, G.; Regnault, J.; Blanchard, P.; Schurr, F.; Ribiere-Chabert, M. Detection of main honey bee pathogens by multiplex PCR. Euroreference 2010, 4, 13-15.

67. Martinello, M.; Baratto, C.; Manzinello, C.; Piva, E.; Borin, A.; Toson, M.; Granato, A.; Boniotti, M.B.; Gallina, A.; Mutinelli, F. Spring mortality in honey bees in northeastern Italy: Detection of pesticides and viruses in dead honey bees and other matrices. $J$. Apic. Res. 2017, 56, 239-254. [CrossRef]

68. Blanchard, P.; Ribière, M.; Celle, O.; Lallemand, P.; Schurr, F.; Olivier, V.; Iscache, A.L.; Faucon, J.P. Evaluation of a real-time two-step RT-PCR assay for quantitation of Chronic bee paralysis virus (CBPV) genome in experimentally-infected bee tissues and in life stages of a symptomatic colony. J. Virol. Methods 2007, 141, 7-13. [CrossRef] [PubMed]

69. Schurr, F.; Tison, A.; Militano, L.; Cheviron, N.; Sircoulomb, F.; Rivière, M.; Ribière-Chabert, M.; Thiéry, R.; Dubois, E. Validation of quantitative real-time RT-PCR assays for the detection of six honeybee viruses. J. Virol. Methods 2019, 270, 70-78. [CrossRef]

70. Blanchard, P.; Olivier, V.; Iscache, A.; Celle, O.; Schurr, F.; Lallemand, P.; Ribière, M. Improvement of RT-PCR detection of chronic bee paralysis virus (CBPV) required by the description of genomic variability in French CBPV isolates. J. Invertebr. Pathol. 2008, 97, 182-185. [CrossRef]

71. Grabensteiner, E.; Ritter, W.; Carter, M.J.; Davison, S.; Pechhacker, H.; Kolodziejek, J.; Boecking, O.; Derakhshifar, I.; Moosbeckhofer, R.; Licek, E.; et al. Sacbrood virus of the honeybee (Apis mellifera): Rapid identification and phylogenetic analysis using reverse transcription-PCR. Clin. Diagn. Lab. Immunol. 2001, 8, 93-104. [CrossRef]

72. Mutinelli, F.; Costa, C.; Lodesani, M.; Baggio, A.; Medrzycki, P.; Formato, G.; Porrini, C. Honey bee colony losses in Italy. J. Apic. Res. 2010, 49, 119-120. [CrossRef]

73. Bellucci, V.; Lucci, S.; Bianco, P.; Ubaldi, A.; Felicioli, A.; Porrini, C.; Mutinelli, F.; Battisti, S.; Spallucci, V.; Cersini, A.; et al. Monitoring honey bee healthin five natural protected areas in Italy. Vet. Ital. 2019, 55, 15-25. [CrossRef]

74. Berényi, O.; Bakonyi, T.; Derakhshifar, I.; Köglberger, H.; Nowotny, N. Occurrence of six honeybee viruses in diseased Austrian apiaries. Appl. Environ. Microbiol. 2006, 72, 2414-2420. [CrossRef]

75. De Smet, L.; Ravoet, J.; de Miranda, J.R.; Wenseleers, T.; Mueller, M.Y.; Moritz, R.F.A.; de Graaf, D.C. BeeDoctor, a Versatile MLPA-Based Diagnostic Tool for Screening Bee Viruses. PLoS ONE 2012, 7, e47953. [CrossRef] [PubMed]

76. Matthijs, S.; De Waele, V.; Vandenberge, V.; Verhoeven, B.; Evers, J.; Brunain, M.; Saegerman, C.; De Winter, P.J.J.; Roels, S.; de Graaf, D.C.; et al. Nationwide Screening for Bee Viruses and Parasites in Belgian Honey Bees. Viruses 2020, 12, 890. [CrossRef]

77. Amiri, E.; Meixner, M.; Nielsen, S.L.; Kryger, P. Four Categories of Viral Infection Describe the Health Status of Honey Bee Colonies. PLoS ONE 2015, 10, e0140272. [CrossRef] [PubMed]

78. Tentcheva, D.; Gauthier, L.; Zappulla, N.; Dainat, B.; Cousserans, F.; Colin, M.E.; Bergoin, M. Prevalence and seasonal variations of six bee viruses in Apis mellifera L. and Varroa destructor mite populations in France. Appl. Environ. Microbiol. 2004, 70, 7185-7191. [CrossRef] [PubMed]

79. Morawetz, L.; Köglberger, H.; Griesbacher, A.; Derakhshifar, I.; Crailsheim, K.; Brodschneider, R.; Moosbeckhofer, R. Health status of honey bee colonies (Apis mellifera) and disease-related risk factors for colony losses in Austria. PLoS ONE 2018, 14, e0219293. [CrossRef]

80. Blanchard, P.; Guillot, S.; Antùnez, K.; Köglberger, H.; Kryger, P.; de Miranda, J.R.; Franco, S.; Chauzat, M.; Thiéry, R.; Ribière, M. Development and validation of a real-time two-step RT-qPCR TaqMan®assay for quantitation of Sacbrood virus (SBV) and its application to a field survey of symptomatic honey bee colonies. J. Virol. Methods 2014, 197, 7-13. [CrossRef] [PubMed]

81. Allen, M.; Ball, B. The incidence and world distribution of honey bee viruses. Bee World 1996, 77, 141-162. [CrossRef]

82. Bacandritsos, N.; Granato, A.; Budge, G.; Papanastasiou, I.; Roinioti, E.; Caldon, M.; Falcaro, C.; Gallina, A.; Mutinelli, F. Sudden deaths and colony population decline in Greek honey bee colonies. J. Invertebr. Pathol. 2010, 105, 335-340. [CrossRef] [PubMed]

83. Dainat, B.; Evans, J.D.; Chen, Y.P.; Gauthier, L.; Neumann, P. Predictive markers of honey bee colony collapse. PLoS ONE 2012, 7, e32151. [CrossRef]

84. Mendoza, Y.; Antúnez, K.; Branchiccela, B.; Anido, M.; Santos, E.; Invernizzi, C. Nosema ceranae and RNA viruses in European and Africanized honeybee colonies (Apis mellifera) in Uruguay. Apidologie 2014, 45, 224-234. [CrossRef]

85. Chagas, D.B.; Monteiro, F.L.; Barcelos, L.D.S.; Frühauf, M.I.; Ribeiro, L.C.; Lima, M.D.; Hübner, S.D.O.; Fischer, G. Black queen cell virus and Nosema ceranae coinfection in Africanized honey bees from southern Brazil. Pesqui. Vet. Bras. 2021, 40, 892-897. [CrossRef]

86. Klee, J.; Besana, A.; Genersch, E.; Gisder, S.; Nanetti, A.; Tam, D.; Chinh, T.; Puerta, F.; Ruz, J.; Kryger, P.; et al. Widespread dispersal of the microsporidian Nosema ceranae, an emergent pathogen of the western honey bee, Apis mellifera. J. Invertebr. Pathol. 2007, 96, 1-10. [CrossRef] [PubMed]

87. Ferroglio, E.; Zanet, S.; Peraldo, N.; Tachis, E.; Trisciuoglio, A.; Laurino, D.; Porporato, M. Nosema ceranae has been infecting honey bees Apis mellifera in Italy since at least 1993. J. Apic. Res. 2013, 52, 60-61. [CrossRef]

88. Maiolino, P.; Iafigliola, L.; Rinaldi, L.; De Leva, G.; Restucci, B.; Martano, M. Histopathological findings of the midgut in European honey bee (Apis mellifera L.) naturally infected by Nosema spp. Vet. Med. Anim. Sci. 2014, 2, 4. [CrossRef] 
89. Stevanovic, J.; Stanimirovic, Z.; Genersch, E.; Kovacevic, S.R.; Ljubenkovic, J.; Radakovic, M.; Aleksic, N. Dominance of Nosema ceranae in honey bees in the Balkan countries in the absence of symptoms of colony collapse disorder. Apidologie 2011, $42,49$. [CrossRef]

90. Mráz, P.; Hýbl, M.; Kopecký, M.; Bohatá, A.; Hoštičková, I.; Šipoš, J.; Vočadlová, K.; Čurn, V. Screening of Honey Bee Pathogens in the Czech Republic and Their Prevalence in Various Habitats. Insects 2021, 12, 1051. [CrossRef]

91. Martínez, J.; Leal, G.; Conget, P. Nosema ceranae an emergent pathogen of Apis mellifera in Chile. Parasitol. Res. 2012, 111, 601-607. [CrossRef]

92. Morimoto, T.; Kojima, Y.; Yoshiyama, M.; Kimura, K.; Yang, B.; Peng, G.; Kadowaki, T. Molecular detection of protozoan parasites infecting Apis mellifera colonies in Japan. Environ. Microbiol. Rep. 2013, 5, 74-77. [CrossRef]

93. Emsen, B.; Guzman-Novoa, E.; Hamiduzzaman, M.M.; Eccles, L.; Lacey, B.; Ruiz-Pérez, R.A.; Nasr, M. Higher prevalence and levels of Nosema ceranae than Nosema apis infections in Canadian honey bee colonies. Parasitol. Res. 2016, 115, 175-181. [CrossRef]

94. Antúnez, K.; Martín-Hernández, R.; Prieto, L.; Meana, A.; Zunino, P.; Higes, M. Immune suppression in the honey bee (Apis mellifera) following infection by Nosema ceranae (Microsporidia). Environ. Microbiol. 2009, 11, 2284-2290. [CrossRef]

95. Betti, M.I.; Wahl, L.M.; Zamir, M. Effects of infection on honey bee population dynamics: A model. PLoS ONE 2014, 9, e110237. [CrossRef] [PubMed]

96. Tritschler, M.; Retschnig, G.; Yañez, O.; Williams, G.R.; Neumann, P. Host sharing by the honey bee parasites Lotmaria passim and Nosema ceranae. Ecol. Evol. 2017, 7, 1850-1857. [CrossRef] [PubMed]

97. Cavigli, I.; Daughenbaugh, K.F.; Martin, M.; Lerch, M.; Banner, K.; Garcia, E.; Brutscher, L.M.; Flenniken, M.L. Pathogen prevalence and abundance in honey bee colonies involved in almond pollination. Apidologie 2016, 47, 251-266. [CrossRef] [PubMed]

98. Doublet, V.; Natsopoulou, M.E.; Zschiesche, L.; Paxton, R.J. Within-host competition among the honey bees pathogens Nosema ceranae and Deformed wing virus is asymmetric and to the disadvantage of the virus. J. Invertebr. Pathol. 2015, 124, 31-34 [CrossRef]

99. Wilfert, L.; Long, G.; Leggett, H.C.; Schmid-Hempel, P.; Butlin, R.; Martin, S.; Boots, M. Deformed wing virus is a recent global epidemic in honeybees driven by Varroa mites. Science 2016, 351, 594-597. [CrossRef]

100. Mondet, F.; de Miranda, J.R.; Kretzschmar, A.; Le Conte, Y.; Mercer, A.R. On the front line: Quantitative virus dynamics in honeybee (Apis mellifera L.) colonies along a new expansion front of the parasite Varroa destructor. PLoS Pathog. 2014, 10, e1004323. [CrossRef]

101. Wu, J.; Zhou, C.; Wu, P.; Xu, J.; Guo, Y.; Xue, F.; Getachew, A.; Xu, S. Brain metabolomic profiling of eastern honey bee (Apis cerana) infested with the mite Varroa destructor. PLoS ONE 2017, 12, e0175573. [CrossRef]

102. Shutler, D.; Head, K.; Burgher-MacLellan, K.; Colwell, M.J.; Levitt, A.L.; Ostiguy, N.; Williams, G.R. Honey bee Apis mellifera parasites in the absence of Nosema ceranae fungi and Varroa destructor mites. PLoS ONE 2014, 9, e98599. [CrossRef]

103. Manley, R.; Temperton, B.; Doyle, T.; Gates, D.; Hedges, S.; Boots, M.; Wilfert, L. Knock-on community impacts of a novel vector: Spillover of emerging DWV-B from Varroa-infested honeybees to wild bumblebees. Ecol. Lett. 2019, 22, 1306-1315. [CrossRef]

104. Gisder, S.; Möckel, N.; Eisenhardt, D.; Genersch, E. In Vivo evolution of viral virulence: Switching of deformed wing virus between hosts results in virulence changes and sequence shifts. Environ. Microbiol. 2018, 20, 4612-4628. [CrossRef]

105. Dainat, B.; Evans, J.D.; Chen, Y.P.; Gauthier, L.; Neumann, P. Dead or alive: Deformed wing virus and Varroa destructor reduce the life span of winter honeybees. Appl. Environ. Microbiol. 2012, 78, 981-987. [CrossRef] [PubMed]

106. Francis, R.M.; Nielsen, S.L.; Kryger, P. Varroa-Virus interaction in collapsing honey bee colonies. PLoS ONE 2013, 8, e57540. [CrossRef] [PubMed]

107. Toplak, I.; Rihtarič, D.; Ciglenečki, U.J.; Hostnik, P.; Jenčič, V.; Barlič-Maganja, D. Detection of six honeybee viruses in clinically affected colonies in Carniolan gray bee (Apis mellifera carnica). Slov. Vet. Res. 2012, 49, 89-96.

108. Tlak Gajger, I.; Šimenc, L.; Toplak, I. The First Detection and Genetic Characterization of Four Different Honeybee Viruses in Wild Bumblebees from Croatia. Pathogens 2021, 10, 808. [CrossRef] [PubMed]

109. Nielsen, S.L.; Nicolaisen, M.; Kryger, P. Incidence of acute bee paralysis virus, black queen cell virus, chronic bee paralysis virus, deformed wing virus, Kashmir bee virus and sacbrood virus in honey bees (Apis mellifera) in Denmark. Apidologie 2008, 39, 310-314. [CrossRef] 